NEITHER TEMPORARY, NOR PERMANENT: THE PRECARIOUS EMPLOYMENT

EXPERIENCES OF REFUGEE CLAIMANTS IN TORONTO

$$
\text { by }
$$

Samantha Jackson, BA, McGill University, 2010

\author{
A Major Research Paper \\ presented to Ryerson University \\ in partial fulfillment of the requirements for the degree of \\ Master of Arts \\ in the Program of \\ Immigration and Settlement Studies
}

Toronto, Ontario, Canada, 2012

(C) Samantha Jackson 2012 


\section{AUTHOR'S DECLARATION FOR ELECTRONIC SUBMISSION OF A MAJOR RESEARCH PAPER (MRP)}

I hereby declare that I am the sole author of this Major Research Paper. This is a true copy of the MRP, including any required final revisions, as accepted by my examiners.

I authorize Ryerson University to lend this MRP to other institutions or individuals for the purpose of scholarly research.

I further authorize Ryerson University to reproduce this paper by photocopying or by other means, in total or in part, at the request of other institutions or individuals for the purpose of scholarly research.

I understand that my MRP may be made electronically available to the public.

Samantha Jackson 


\title{
NEITHER TEMPORARY, NOR PERMANENT: THE PRECARIOUS EMPLOYMENT EXPERIENCES OF REFUGEE CLAIMANTS IN TORONTO
}

(c) Samantha Jackson 2012

\author{
Master of Arts \\ Immigration and Settlement Studies \\ Ryerson University
}

\begin{abstract}
While Canada's immigration system is shaped primarily by the nation's economic needs, refugee claimants' motivations are, by nature, non-economic. Resultantly, refugee claimants are often portrayed as a drain on Canadian resources. Despite this however, refugee claimants' employment experiences remain underrepresented in the literature. This study explores the employment experiences of refugee claimants in Toronto, and finds that claimants face distinct and unique barriers stemming from their precarious legal status. Additionally, as neither temporary workers nor permanent citizens, this study finds that refugee claimants perceive employment as an integrative expression of belonging and citizenship. Through the lens of refugeeness, this study traces the subjective employment trajectories of refugee claimants. Findings indicate that refugee claimants' employability is shaped by real and ascribed barriers associated with their citizenship status, creating decidedly unique and often difficult employment experiences.
\end{abstract}

Keywords: refugee claimants, refugeeness, bogus refugee, employment barriers, employment experiences 


\section{ACKNOWLEDGEMENTS}

I wish to thank my supervisor, Dr. Harald Bauder, for his constructive and detailed feedback throughout the MRP process. I also extend a sincere thank you to all of my participants, who shared their personal experiences in exploring and navigating their new identities. Finally, I wish to thank the settlement agencies that generously facilitated my participant recruitment process. 


\section{DEDICATION}

For my parents, Shelley and Nick. 


\section{Table of Contents}

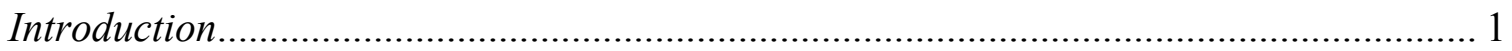

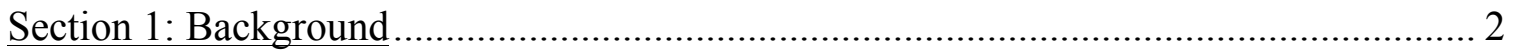

Refugee Claimants: Numbers and Context ......................................... 2

Theoretical Framework: Constructed Representations and Refugeeness ............... 3

Refugee Representations and Discourses .............................................. 7

Established Skills, New Hurdles: A Review of the Literature.............................. 9

Language Skills and Recognition.................................................... 12

Canadian Experience ......................................................................... 12

Refugee Claimant-Specific Barriers ................................................. 13

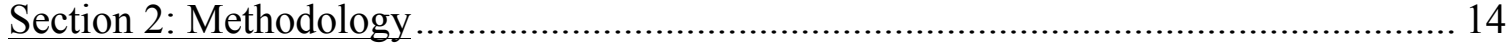

Approach ................................................................................ 14

Strategy and Data Collection Tools .................................................. 14

Recruitment Strategies and Sampling .............................................. 15

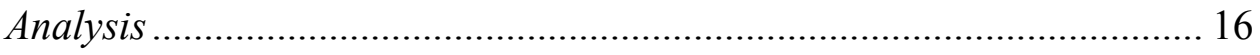

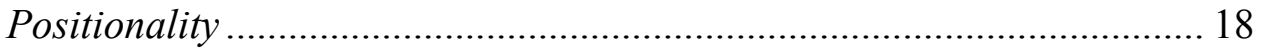

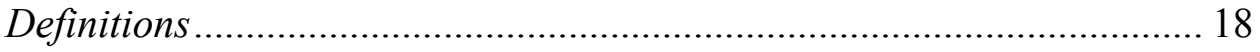

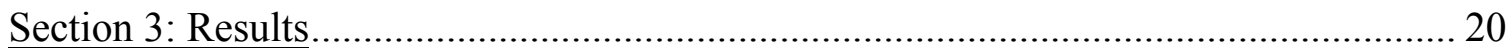

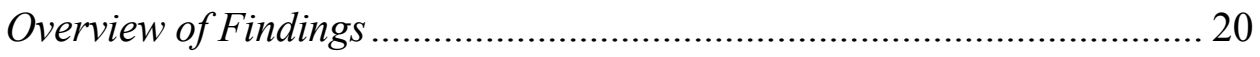

3.1 Barriers to Refugee Employment......................................................................... 22

"The First Step in Finding a Job":

Improving English as Enacting Agency .............................................. 23

Nested Barriers: Blockades to Bridging and RC Volunteerism............... 24

The 900 Series SIN: Marking 'Refugee' and Limiting Employability ...... 26

Ascribing Capabilities: 'Refugeeness' and Employability ....................... 28

Ascribing Identities: Negative Discourse and Employability .................. 30

The 'Space Between': the Distinctiveness of RC Labour ....................... 32

3.2 The Distinct Experiences and Expressions of RC Employment.............................. 36

Employment as an Expression of Citizenship ................................................. 36

Employing, Engaging and Re/Defining Identities ........................................... 39

Volunteering Time, Reclaiming Identities............................................ 39

Government Assistance and Identity: 'Welfare' and the Refugee Claimant ........ 41 
Reduced Healthcare, Reduced Employability? Protecting Canada's Immigration

System Act and IFHP: an Overview ............................................................... 44

Changing IFHP Policy and RC Employability ...................................... 45

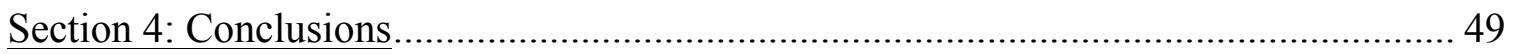

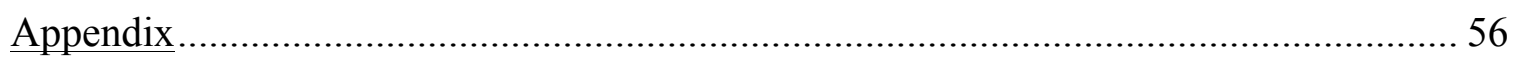

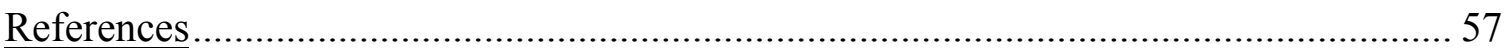

\section{List of Tables}

Table 1: Sociodemographic Information.......................................... 19

\section{List of Acronyms}

\begin{tabular}{|l|l|}
\hline RC & Refugee Claimant \\
\hline IRB & Immigration and Refugee Board \\
\hline DCO & Designated Country of Origin \\
\hline IFHP & Interim Federal Health Program \\
\hline PIF & Personal Information Form \\
\hline SIN & Social Insurance Number \\
\hline H\&C & $\begin{array}{l}\text { Humanitarian and Compassionate } \\
\text { Consideration }\end{array}$ \\
\hline MOH & "Making Ontario Home" \\
\hline ESOL & English for Speakers of Other Languages \\
\hline GAR & Government-Assisted Refugee \\
\hline IFHP & Interim Federal Health Program \\
\hline
\end{tabular}




\section{Introduction}

Refugees have both embodied and facilitated Canada's national humanitarian identity since Canada ratified the United Nations Convention Relating to the Status of Refugees in 1969 (Becklumb, 2008). Citizenship and Immigration Canada (CIC) (2012) highlights this mutually beneficial relationship, stating that refugees "bring their experiences, hopes and dreams to Canada to help build an even richer and more prosperous society for us all" ("What Canada is Doing to Help Refugees", 2012). However, in the wake of neo-liberal reforms, the economic cost of Canada's commitment to humanitarianism is under fire, and the notion of inland refugee claimants as a precept to the Canadian identity is questioned through mounting negative public discourse.

Yet, despite an increased focus on refugees' economic costs, the employment experiences of inland refugee claimants (RCs) remain understudied. This study seeks to help fill this gap by examining the labour market experiences of refugee claimants in Toronto, and exploring the questions, what employment barriers do refugee claimants face? What does employment mean for refugee claimants? This study engages Dobson's (2004) refugeeness framework as a lens to observe the subjective trajectories of refugees' employment experiences, as well as tenets from Pozniak (2009) to situate the power of public narratives in shaping RCs' employability. I first explore the employment barriers faced by RCs, and follow with an analysis of claimants' labour market experiences to explore the integrative role employment plays in shaping RCs' cultural ontologies. It will be demonstrated that refugeeness projects unique challenges unto its bearers and ultimately, shapes RCs' experiences and understandings of employment in Canada. 


\section{Section 1: Background}

\section{Refugee Claimants: Numbers and Context}

In Canada, potential refugees may enter through one of three streams: as an inland refugee claimant (RCs), as a Government-Assisted Refugee (GAR), or through the Private Sponsorship of Refugees program (PSR). Both GARs and PSRs are individuals living outside of Canada who fit the refugee criteria, as defined by the 1951 Geneva Convention and its 1967 Protocol (CIC "The Refugee System", 2012). People are determined to be GARs and PSRs by CIC officers overseas, and once successful, are sponsored by individuals or the Canadian government to be resettled in Canada. Conversely, RCs are already in Canada. These prospective claimants arrive in Canada through their own means, and typically make a refugee claim at their point of entry, such as an airport. Through a process that can take several months or even years, claimants have their case heard at the Immigration and Refugee Board, where it is determined if they are a refugee, pursuant to the same criteria used to determine GARs and PSRs.

In 2011, 10,741 new refugee claimants entered Canada (CIC, 2011). Within the top ten source countries, three participants' countries are represented: Mexico, Colombia, and Hungary. In the same year, of the 24,983 total cases referred to the Immigration and Refugee Board (IRB), 38\% were accepted. Although these numbers may seem generous, ten years prior, in $2001,43,996$ cases were referred and a notable $47 \%$ were accepted as Convention refugees (CIC “Preliminary Tables”, 2011).

While these numbers might indicate changing trends in Canada's hospitality towards refugee claimants, in terms of accessibility, institutional frameworks remain largely permissive towards refugee claimants. Canada is unique in that while waiting for 
one's refugee determination hearing or pursuing alternative routes of appeal, such as Humanitarian and Compassionate $(\mathrm{H} \& \mathrm{C})$ consideration, refugee claimants can apply for a temporary work permit and Social Insurance Number (SIN). These documents allow refugee claimants to legally work in Canada during this "critical period integral to urban re-settlement" (Manjikian, 2010 p. 51). Claimants who have been referred to the IRB can apply for these work permissions by submitting a Personal Identification Form (PIF) and all medical examinations to CIC, amounting to an average wait of two months (FCJ Refugee Centre, "Work Permits and SIN", n.d.). There is no cost for refugee claimants to obtain a work permit or SIN (CIC Document Checklist, 2010).

Refugee claimants also have access to a variety of other services, including free language training and employment assistance. The Ontario Council of Agencies Serving Immigrants' comprehensive survey of newcomers' settlement service use, Making Ontario Home (MOH), finds $53.1 \%$ of refugee claimants who arrived in Canada in the past ten years use general settlement services. $M O H$ also finds that despite $54.3 \%$ of RC using employment services within their first year of arrival, a full $58.6 \%$ reported "experiencing challenges in finding employment when they settled in their current cities" (Ali et al., 2012 p. 36).

\section{Theoretical Framework: Constructed Representations and Refugeeness}

As this research is framed to explore the subjective labour market experiences of RCs, refugeeness is engaged as a theoretical framework to understand how one's identity and experiences as a refugee shape and form employment experiences. Refugeeness is broadly employed to illustrate how participants' experiences becoming a refugee shape their experiences as a refugee; within this context of employability, refugeeness is 
understood as an ongoing, constitutive process, with each 'refugee experience' building on the last and shaping the next.

While it has been argued that "the experience of being a refugee is defined as being universal to those who experience it" (Lacroix, 2004 p. 148), this framework is grounded in Dobson's (2004) assertion that "it is a mistake to regard the refugee as...a member in a mass group in flight" (p. 23), and employs refugeeness as a means of understanding individual's subjective experiences interacting with the refugee identity.

Certainly, the formation of one's refugeeness is largely the product of interactions with institutions. Resultantly, Malkki (1995) conceives of refugeeness as "a way of understanding the particular subjective experience [of the refugee] in relation to existing policies" (p. 497). Similarly, Lacroix (2004) argues that understanding the refugeeness process involves understanding both the institutions that shape a refugee's experiences, such as the refugee definition, and subsequently, the experiences that stem from interactions with these structures: "[u]nderstanding refugeeness starts with definitions", writes Lacroix, "and moves beyond to consider the individual's subjective experience of having to flee one's country" (p. 149).

The author further asserts that the process of refugeeness begins with one's experience fleeing the country, and the subsequent subjective experience of becoming $a$ refugee - that is, negotiating one's identity vis-à-vis the refugee title and subsequently, creating a refugee lens through which one interprets their experiences. Dobson (2004) supports this view, and argues that refugees "take their self-identity from a number of overlapping discourses" (p. 17). The formation of one's refugeeness begins with being forced from one's home and subsequently, interacting with refugee institutions; once 
refugees, people begin "rebuilding their subjectivity, their sense of who they are" (Lacroix, 2004 p. 156). One's refugeeness then, as conceived by Malkki, Lacroix, and Dobson, is constituted by experiences engaging with the refugee process, institutions, and identity.

Specifically, Lacroix (2004) finds interacting with economic, family, and bureaucratic institutions as a refugee largely constitute one's refugeeness. However, this research indicates that RCs' interactions with objective, external refugee discourses are also critical in shaping their identity as a refugee. Resultantly, I assert that objective understandings critically shape participants' subjective experiences and ultimately, their refugeeness. This seemingly contradictory intersection illustrates how encountering others' perceptions of refugees shape RC ontologies. Subsequently, I employ Pozniak's (2009) discussion of the power of external discourses - specifically, the 'bogus refugee' discourse - to illustrate how external narratives act as critical sites to forming one's refugeeness.

Pozniak (2009) explains that recent immigrants are aware of the good v. bad immigrant discourse, and in turn, appropriate their own experiences within the 'good' framework to distinguish themselves as hard-working immigrants. This paper builds upon Pozniak's (2009) findings, and asserts that good v. bad refugee narratives do not just serve "as a prism through which newcomers construct their experiences and identities" (Pozniak, p. 188), but also act as strong factors shaping RCs' experiences, as well as identities ascribed to them by non-refugees.

Understanding the role such narratives play in shaping a refugee's identity is predicated on the assumption that identities are largely relational. This supposition is 
supported in the works of Létourneau (2001), who asserts that identity construction is largely based in its social context; similarly, Dobson (2004) notes the relational nature of identity, and argues that "“'refugees....are defined, determined and take their self-identity from a number of overlapping discourses" (p. 17). This paper finds that public refugee narratives are critical in shaping refugee employability. The process of refugeeness creates unique employment barriers, and ultimately, shapes RCs' integrative employment experiences. Critically, this paper does not suggest RCs' identities are derived entirely from the media; rather, this paper focuses not on how RCs' self-identify as RCs, but how identities are ascribed to them, and the role these ascribed identities play in shaping RCs' employability. Refugeeness then emerges as a way of understanding the employment experiences of refugees as they confront and navigate their ascribed identities.

Additionally, as will be demonstrated in Government Assistance and Identity: 'Welfare' and the Refugee Claimant, the relationship between power, discourse, and ascribing identities is not unique to RCs, but, as demonstrated by Hancock (2004), echoes the use of the Welfare Queen imagery as a tool in economic policy. Finally, this paper will demonstrate that the culmination of these factors amount to the relegation of refugees to certain employment sectors, creating what participants deemed "refugee jobs". This concept will be explored using Bauder's (2006) understanding of migrant labour within the segmented labour market. The following sections aim to inform this paper's research questions by exploring how RCs are situated in current public discourse, and investigating issues established as barriers to immigrant employment. 


\section{Refugee Representations and Discourses}

As this study's research questions were formed in light of the shifting public refugee discourse, a brief discussion of this topic is warranted. Although it is not within the scope of this paper to execute a true discourse analysis, several key points regarding refugee representations, and relatedly, the power of ascribing identities to refugees, ought to be noted.

Pozniak (2009) finds there to be an ongoing construction of immigrant identity narratives in both government and media discourse that dichotomize the "good and bad immigrant" (p. 178). While 'good immigrants' are skilled, hard-working, quick-to-adapt newcomers who never require government assistance, 'bad immigrants' represent a cost to the Canadian taxpayers. These supposed 'bad immigrants' are, according to Pozniak (2009), those who do not learn English, who frequent government assistance, who will not work in low-paying positions, and who are "unwilling to adapt to Canadian norms" (p. 178). This may be further reduced to pertain to refugee claimants specifically, so that in addition to the characteristics of a 'bad immigrant', a 'bogus refugee' is also a queuejumper, or an illegitimate claimant who entered Canada intent on abusing social benefits. Bauder (2008) explains that these terms are used to "represent a category of refugee applicants who are not only undesired but who also inflict damage by consuming the resources needed to support 'deserving' refugees" (p. 89), creating an overall environment of distrust and distaste towards RCs.

Creese (1992) argues this negative dialogue focusing on 'bogus refugees' and more widely, refugees' place within Canada, emerged alongside the 1987 arrival of the Amelie, a boat carrying $173 \mathrm{Sikh}$ refugee claimants. The apparent ability for anyone to 
permeate Canada's borders was a sensational media focus, creating a national uproar that led to the creation of Bill C-55 and subsequently, the Immigration and Refugee Board. Similarly, in 1999, when Chinese boats arrived carrying 599 refugees, the media again represented these arrivals as "racialized, illegal, and non-belonging" (Bauder, 2008 p.85). This sequence was repeated in 2010, with the arrival of the Sun Sea carrying 492 Tamils from Sri Lanka (Toronto Star, "Instances of", 2010). The latest arrival of 'boat people' again caused a media panic and an increasing focus on security-based discourse vis-à-vis Canada's immigration system (Bradimore and Bauder, 2011).

More recently, public concern and discourse has shifted from fearing illegal 'boat people' arrivals to questioning if Canada's refugee determination system is adequately prepared to deal with waves of inland refugee claimants arriving from countries not traditionally conceived of as refugee-sending nations, including the Czech Republic and Hungary. Resultantly, questions now center on whether RCs can originate from democratic states or often, Canada's trading partners. Representatives from Citizenship and Immigration Canada suggest not, and label these claimants are "bogus" economic migrants who enter Canada to forgo work for welfare (National Post, "Tories sweeping", 2012). As suggested in previous discourse analyses, (e.g. Mann, 2009), distrust for RCs and fear of their rising costs is normalized through government press releases, and perpetuated through media outlets. As government officials continue to suggest that RCs arrive at the airport and ask, "... where they can get their welfare cheque from" (National Post, "Tories sweeping", 2012) it is of little surprise RCs' place in Canada is under scrutiny. Cresswell and Merimen (2011) argue the use of this "language of alterity" is not only divisive, but dangerously permits "the homogenization of RC experiences" (p. 260). 
Certainly, in the midst of economic recession, a national refugee discourse rooted in financial costs remains an important policy tool. According to Pozniak (2009), public discourse distinguishes between two different categories of immigrants: solicited immigrants who are economic assets, and unsolicited immigrants who are costly liabilities. The use of 'bogus refugee' discourse is largely rooted in economic costs, and critical to this research, creates an environment of suspicion towards RCs that shape their settlement and labour market experiences. However, "although media discourse establishes boundaries separating 'genuine' and 'bogus' refugees”, explains Bauder (2008), "the allocation of refugee applicants to either side of the boundary is not always a straightforward choice" (p. 89). With few indicators to assist the public in distinguishing exactly which refugees are 'bogus', these labels and discourses blanket and shape RCs' daily lives. As this research's findings will demonstrate, these narratives compromise RCs' ability to attain employment and subsequently, enjoy its various integrative effects.

\section{Established Skills, New Hurdles: A Review of the Literature}

As this study aims to fill the research gap on refugee claimants' labour market experiences, an exploration of the existing newcomer employment literature is necessary. Indeed, the body of literature exploring newcomers' employment barriers is extensive and well developed; however, the literature is equally notable for its limited scope. While innumerous publications explore immigrants' employment barriers in great depth (e.g. Reitz 2001, Bauder 2003, Hadak et al., 2010), research on other 'newcomer streams' is restricted. I argue that as research has largely focused on immigrant newcomers and rarely on refugee claimants as a distinct category, many formidable and distinct barriers attributable to refugee claimants' unique status may be underexplored. In the face of 
increasingly harrowing labels and a focus on refugee claimants as a negative economic burden, the need to fully explore refugee claimants' labour market experiences is increasingly prudent. Speaking generally, however, the literature suggests there are many pronounced barriers facing all streams of newcomers, preventing those who wish to find employment from attaining it.

As previously mentioned, research on refugees' difficulties is fairly limited. Often, statistics on refugee claimants are compiled alongside Convention refugees and recent immigrants (Coates \& Hayward, 2005). This conflation camouflages important differences in the streams' needs, with possibly negative policy implications for RCs. Despite media and government criticisms of refugees' economic cost to Canada, research and statistics relating to claimants and employment remain largely underreported and rarely analyzed.

Below I review several studies exploring barriers to employment reported by immigrants of all streams, government-assisted refugees (GARs), and anecdotally, RCs. This review enables me to infer potential employment barriers that affect RCs.

\section{Credential Recognition}

Across studies and disciplines, credential recognition continually presents as a barrier for newcomers of all streams. Despite disproportionately affecting the economic class, a review of the literature suggests Convention refugees also encounter problems translating their credentials into Canadian employment. In a rare study focused on government-assisted refugees, Krahn el al. (2005) found that although $44 \%$ of 525 interviewed GARs reported credential recognition issues, 25\% of mostly European 
respondents stated they were able to find positions similar to their former professions ( $\mathrm{p}$. 68). However, most participants reported finding only irregular or undesirable employment, and the majority was unable to find employment appropriate to their educational and professional background. However, the authors do not report on factors such as successful GARs' grasp of English, nor which professional fields successful GARs worked in. As findings by Teelucksingh and Galabuzi (2004) suggest, labour market shelters such as accreditation boards are often instrumental in an industry's ability to recognize foreign credentials.

Coates and Hayward (2005) suggest the adjudicating of foreign credentials is shared jurisdiction for both policy makers and accreditation boards, Focusing on credential recognition issues at the institutional level, citizenship status is argued to bear a greater effect on credentials and licensing than source country or discrimination (p. 80). The authors argue some industries are out of reach because necessary licensing or credential recognition is available to permanent residents or citizens only, such as in truck driving (p.82).

Interestingly, amidst these discussions of credential recognition issues, DeVoretz et al. (2004) present yet another barrier common amongst refugees and claimants: arriving without any educational or professional credentials to be recognized. This assessment of 1980-2001 refugee economic indicators finds that only $20 \%$ of refugees from non-European countries arrived in Canada with post-secondary education, compared to over 50\% from Europe (p.9). Krahn et al. (2005) report that GARs often arrive with earned credentials, yet without hardcopy proof. As refugee claimants are often forced to flee with little notice or preparation, many "arrive without transcripts or 
certificates, and the country they have fled may be reluctant or unable to provide copies of such documents", leading to experiences of underemployment or unemployment (Krahn et al p. 36).

\section{Language Skills and Recognition}

Interestingly, newcomers' English capabilities are strongly linked to their country of origin, not the citizenship stream under which they entered. Beiser and Hou (2000) find refugees stemming from areas other than Europe, such as Southeast Asia, have the lowest post-secondary education levels but the highest linguistic capability (p. 8). The authors note that English proficiency is often a greater indicator of long-term career attainment than other forms of credentials (p. 9). Similarly, DeVoretz et al. (2004) report that from 1980-2001, despite arriving with statistically less formal education, nonEuropean claimants were much more likely to speak English (p. 10). Krahn et al. (2005) found that GAR participants felt English language training programs to be inadequate (p. $81)$.

\section{Canadian Experience}

Across the reviewed studies, disenchanted respondents repeated encounters with what Mata refers to as the "trap in the accreditation cycle" - in order to get Canadian experience, one needs Canadian experience (Mata, 1999 p.5). Interestingly, research largely indicates foreign-trained professionals were perplexed as to why Canadian experience was required by employers and angered at the implied devaluing of their often

decades of experience (Krahn et al. 2005, Azuh 1998, Reitz 2007). Succinctly, Bauder 
suggests requiring ambiguous Canadian work experience is merely a method to devalue immigrant labour (Bauder, 2003).

Several studies reported newcomers volunteering in fields related to their profession in order to gain Canadian experience, or volunteering in any position in order to attain Canadian references. Krahn et al. (2005) reported a notable 34\% of participants completed volunteer work in order to gain experience (p. 76). Conversely, Lacroix (2004) found participants wary of volunteering for experience as they understandably questioned its benefits to advancing their careers. A Rwandan doctor, aware of the difficulties foreign-trained, physicians felt unable to volunteer in hospitals. "I can't, the frustration would be too much", he states, "For what I have been, it's very frustrating" (p. 157).

\section{Refugee Claimant-Specific Barriers}

Although some publications touch upon barriers faced by refugee claimants, it is notable that no author focused specifically on employment barriers faced by refugee claimants, nor was the uniqueness of refugee claimants' precarious status fully explored as a potential employment barrier. Despite discussing the experiences of Convention refugees in addition to refugee claimants, Coates and Hayward (2005) did argue the label of "refugee claimant" leads to discrimination through markers such as 900 -series SIN numbers and an inability to commit to long-term work (p. 85). While not elucidating if issues such as SIN numbers contributed to its findings, in its groundbreaking study Making Ontario Home (2012) reported over half of interviewed refugee claimants experiencing difficulty finding work. Resultantly then, many claimants are forced to turn to government assistance. Not surprisingly, Lacroix (2004) finds all claimants interviewed felt "humiliated" by the fact that they were professionals on welfare; this, 
compounded with their fear of no longer being "socially valued and contributing members of society", amounted to deflated self-image, which may further hamper their employment prospects (2004, p. 158).

Based on the literature review above, it is evident that newcomers across all streams face structural as well as institutionalized barriers, such as devalued credentials, that inhibit one's ability to maximize human capital.

\section{Section 2: Methodology}

\section{Approach}

As this study seeks to explore participant's personal experience in relative depth, it employs a qualitative research approach. Semi-structured interviews that include openended questions allowed me to guide the conversation while simultaneously facilitating the participant's own digressions, which proved to be rich sources of data. This study's exploratory nature allowed for in-depth investigations of interviewees' personal experiences. As this sample size is relatively small, and this research is subject to financial and time constraints, the qualitative approach is practical and beneficial while allowing for thorough exploration of these research questions.

\section{Strategy and Data Collection Tools}

This study maintained a grounded theory approach. Grounded theory acknowledges that the researcher brings with her biases and a theoretical framework, however permits the researcher to keep an open mind when exploring the research question (Wesley, 2011). Indeed, although the study's strategy stems from my own 
experiences and has been informed by research on similar populations, this study did not seek to prove a specific hypothesis; rather, this study sought primarily to explore the employment experiences of refugee claimants. An informal acknowledgement of hostile public refugee discourses, and a preliminary understanding of the labour market experiences of newcomer streams, informed interview questions.

As both grounded theory and the concept of refugeeness stem from the notion of allowing the subject to define itself, these concepts merged well and served to inform the research questions. Resultantly, interviews were structured to avoid leading the interviewee, and questions posed were largely open-ended. Data garnered from interview questions was analyzed using publications from peer-reviewed academic journals and other academic works; these publications were largely theoretical in focus, exploring the aforementioned refugeeness framework. Finally, existing statistical data was taken from Stats Can and Making Ontario Home in order to substantiate, compliment and inform this analysis.

\section{Recruitment Strategies and Sampling}

Participants were recruited through the use of research recruitment posters. Recruitment posters detailed all pertinent information about the study including its purpose, participant selection criteria, the gift card incentive provided for all participants, and my contact information. With permission from service coordinators, posters were placed in four refugee settlement agencies within Toronto. Service coordinators were instrumental in advertising this study, presenting the research poster to potential participants they believed might be interested. 
In total, seventeen interviews were conducted in mutually neutral locations, such as in a private room at the University of Toronto library. As two participants were determined to not fit the selection criteria, these interviews were discarded, leaving a purposive sample of fifteen participants. The resulting sample was diverse, allowing for a variety of perspectives from varying stages of the refugee determination process. Participants were Toronto residents over eighteen years of age, had made a refugee claim in Canada in the past five years, and were within the parameters of the refugee claimant process at the time of interviewing. Should the participant have received a positive refugee determination decision, this decision must have been rendered in the past two years, effectively barring Canadian citizens. Fourteen out of fifteen interviews were conducted in English, with one interview being conducted in Spanish with the help of a translator. This information can be found in Table 1 on p. 19 .

\section{Analysis}

All interviews were digitally audio-recorded and transcribed. The analysis followed Anselm Strauss' (1987) prescribed methods of data analysis for grounded theory. I read through all transcripts continuously in order to gain a broad understanding of their contents. Each transcript was then individually analyzed using open coding, during which broad thematic labels and core codes were discerned. Transcripts were then selectively coded as smaller codes were noted. This method is established as effective for comparing and contrasting data in order to note interesting discrepancies and similarities (Wesley, 2011). Transcripts were coded one of three colours to denote thematic codes, or core codes; descriptive coding, which noted participants' descriptions of events or perceptions; and objective coding, denoting objective facts, such as sociodemographic 
data. Links between the core and sub codes were noted throughout the coding process, and revised as new codes emerged. Following the trajectory of grounded theory research, a descriptive memo was written to highlight pertinent themes and linkages. Codes were then arranged hierarchically, and aggregate lists created to organize, pair and note thematic connections and relationships between codes, which prepared the analyzed data for final analysis.

\section{Ethical Considerations}

According to Gillis and MacLennan (2010), vulnerable groups are populations with unmet needs, social limitations, and precarious statuses that are "embedded in systems of inequality" (p.1). Faced with precarious citizenship status and various other barriers, refugee claimants are certainly considered a vulnerable population. To address this vulnerability and limit misunderstanding, all recruitment posters were written in English, and participants were advised questions could be repeated or rephrased at any time.

As well, ethical considerations regarding participants' perceptions of power imbalances were considered. Gillis and MacLennan (2010) note issues such as precarious citizenship status may lead to people participating out of feelings of obligation or fear ( $p$. 12), what Archer and Berdahl note as "the interviewer effect" (2011, p. 179). In order to minimize this risk, all participants were advised of their rights, including their ability to pause or stop the interview at any time. Additionally, all participants were reminded that their name and any affiliation with a settlement agency or workplace will remain confidential at all times. 


\section{Positionality}

"It is important for researchers to consider what they are doing and how and why they are doing it, as well as thinking about who they are", writes Hopkins (2007, p. 387). Certainly, the idea of full disclosure of the interviewer is pertinent to this study, as it was my own informal discussions while volunteering at a Toronto settlement agency and academic focus on immigrant labour market outcomes that led me to notice the lack of research available regarding refugee claimants' employment experiences. Wesley (2011) notes that the researcher's "personal imprint" is an "unavoidable element" of qualitative study (p. 128); however, as this study employs the strategy of grounded theory, it was still critical that my own personal experiences and biases did not lead the interviewees' answers, nor slant the analysis in a manner that would compromise this study's integrity and validity. Resultantly, questions were formatted to avoid leading interviewees, and were largely open-ended to facilitate participants to speak more or less about issues they believe to be important.

\section{Definitions}

This paper focuses on the experiences of RCs in the workforce. However, the terms refugee claimant, refugees, and $\mathrm{RC}$ are used interchangeably to denote someone who falls within the refugee claimant spectrum: a person who has arrived in Canada as an inland refugee claimant, and is awaiting an IRB hearing or pursuing an alternative form of appeal. This includes people who have been rejected at the IRB, and are currently applying for Humanitarian and Compassionate $(\mathrm{H \& C})$ consideration. Finally, this

research engages Goldring's use of precarious status as a term to "capture the insecurities of less than full status" (p. 50). 
Table 1: Participant Sociodemographic Information

\begin{tabular}{|c|c|c|c|c|}
\hline Interviewee: & Gender: & CO: & YA: & Status: \\
\hline 1. Adela & $\mathrm{F}$ & El Salvador & 2009 & H\&C (RC denied) \\
\hline 2. Bernardo & $\mathrm{M}$ & Columbia & 2008 & PR (RC accepted) \\
\hline 3. Carisa & $\mathrm{F}$ & El Salvador & 2012 & $\mathrm{RC}$ \\
\hline 4. Dante & $\mathrm{M}$ & El Salvador & 2012 & $\mathrm{RC}$ \\
\hline 5. Elias & $\mathrm{M}$ & Mexico & 2005 & $\begin{array}{c}\text { Beginning H\&C } \\
\text { process (RC denied) }\end{array}$ \\
\hline 6. Flor & $\bar{F}$ & Mexico & 2008 & $\begin{array}{l}\text { TR (RC denied, H\&C } \\
\text { accepted) }\end{array}$ \\
\hline 7. Gil & $\mathrm{M}$ & Honduras & 2008 & PR (RC accepted) \\
\hline 8. Herminia & $\mathrm{F}$ & Mexico & 2007 & $\begin{array}{l}\mathrm{TR} \text { (RC accepted, delay } \\
\text { in receiving PR) }\end{array}$ \\
\hline 9. Inez & $\bar{F}$ & Columbia & 2011 & $\mathrm{RC}$ \\
\hline 10. Jon & $\mathrm{M}$ & El Salvador & 2012 & $\mathrm{RC}$ \\
\hline 11. Katia & $\mathrm{F}$ & Mexico & 2006 & $\begin{array}{c}\text { Beginning H\&C } \\
\text { process (RC denied) }\end{array}$ \\
\hline 12. Lazar & $\bar{M}$ & Hungary & 2011 & $\mathrm{RC}$ \\
\hline 13. Malik & $\mathrm{M}$ & Turkey & 2012 & $\mathrm{RC}$ \\
\hline 14. Nelia & $\mathrm{F}$ & Columbia & 2009 & $\mathrm{H} \& \mathrm{C}$ ( $\mathrm{RC}$ denied) \\
\hline 15. Omer & $\mathrm{M}$ & Columbia & 2011 & $\mathrm{RC}$ \\
\hline
\end{tabular}




\section{$\underline{\text { Section 3: Results }}$}

\section{Overview of Findings}

Although the subjectivities of participants are decidedly individual, many respondents shared similar labour market experiences. This introduction gives an overview of observable trends and variances in participants' employment experiences as RCs in Toronto.

Firstly, participants came from a diverse yet largely skilled background: seven respondents had post-secondary education, including two who worked in regulated professions; four were skilled workers; and four respondents arrived with unskilled work experience. Previous positions included university professors, autoworkers, two land dispute mediators, and a customer service agent. Interestingly, both land dispute mediators identified involvement in their former position as instigating their persecution.

Positions held once arriving in Canada were noticeably similar. With the exception of one man who managed a retail store, all other RCs worked in one of four industries: construction, cleaning, general labour, or in a kitchen. Most respondents had worked several positions since their time of arriving in Canada, nearly all of which were temporary and part-time. Additionally, three female respondents provided childcare at no charge, unpaid work they did not perceive as Canadian experience.

These positions were attained in similar fashions. The majority of respondents cited the use of cultural and social networks as instrumental in their job search, followed by job search agencies, the Internet, and handing in resumes to retailers, a method that proved successful for only one participant. Two respondents were currently employed 'under the table', and four respondents had used informal employment networks at some 
point when they were unable to find other positions. Regardless of skill level however, all participants reported experiencing downward mobility. The often unique, if not astounding experiences of refugee claimants' downward mobility is evident in Giulio's recollection:

I worked for a woman's clothing store. It was so funny because first I was dealing with land disputes and had six death attempts. One of them I got thrown out of a police SUV and two of my bodyguards and one of my lawyers were killed. And a year later I was selling women's dresses. It was pretty crazy.

Instances of downward mobility, such as from psychologist to kitchen helper or from university professor to duct cleaner, were "a big change" (Katia) for most respondents, who often felt powerless within both their new position and their ability to change their situation. It is important to consider the intersectionality of these factors, as newcomers' oft-encountered barriers to employment rarely exist in isolation.

All participants had engaged with a settlement agency in some way. The most frequent reasons for contacting settlement agencies were to seek assistance with attaining a Social Insurance Number and work permit, to secure employment, and to find housing. Almost three-quarters of participants sought language assistance through English for Speakers of Other Languages (ESOL) classes at some point during their refugee process. Similarly, five respondents reported seeking assistance from employment specific agencies, slightly less than the $60.2 \%$ that reported using similar services in Making Ontario Home (2012, p. 38).

The following discussion explores this study's two-pronged research question: what employment barriers do refugee claimants face? What does working mean for refugee claimants? As mentioned, the importance of external narratives in shaping 
refugeeness is engaged in order to better understand the distinct experiences of refugee claimants.

\subsection{Barriers to Refugee Employment}

Participants stated that because of their impermanent precariousness, they encountered various barriers that limit RCs' potential. Challenges encountered included language barriers, devalued credentials, and issues relating to assumptions regarding RCs' worth and capabilities.

\section{Language Barriers: Powerlessness and Proficiency}

Despite all but one participant interviewing in English, all participants described language proficiency as their most formidable employment barrier. Participants stated that while they could understand others, being understood was more difficult. Supporting findings by Hosada (2009), eight participants attributed this to their accent: "It is necessary for more English because Canadian people say, 'I no understand!'” explained Nelia; "some people laugh at me...because the accent of Latin is very not easy for you Canadians to understand". Just as England (1996) noted language as a factor in the devalued migrant identity construct, three participants felt coworkers dismissed them as 'incompetent' because of these language limitations. This relegation to incapable Other evoked vivid imagery from participants; the inability to express oneself, stated Bernardo, leaves one feeling "mutilated; as though you cannot speak". Such responses indicate participants felt disempowered and angered by these 'misunderstandings', as participants described being dismissed and perceived incapable by potential employers and 
coworkers; a discussion of ascribed refugee identities will explore this concept in greater depth.

\section{“The First Step in Finding a Job”: Improving English as Enacting Agency}

Interestingly, however, language barriers were not necessarily perceived as static:

I went to the [English] school because they told me we had to go to the school, but I liked to and I wanted to learn the language...my friends said, 'you have to learn English to have opportunities we don't have in our countries'. And I felt very excited for that news. (Inez)

Indeed, while the inability to communicate was described largely as "extremely frustrating" (Carisa), as a barrier for RCs, it is also the most conquerable. Six responses indicate that while other barriers such as education were perceived as "too expensive" for RCs to overcome, improving language was facilitated by free ESOL classes or often, through social networks and even workplace practice. This supports findings by Prefontaine and Benson (1999), who indicate language to be the most "acquirable" form of human capital (p.19); language, describes Flor, is "the first step in finding a job". Interestingly, Giulio experienced the reverse, and accepted a retail position he knew would better his English. Although working in construction was more profitable, "I wouldn't practice my language and then it would take me even more [time] to get something in my field", he recalls; "I was just focused on learning language".

Giulio's experience, although unique in some aspects, is representative of the many important trade-offs refugee claimants must make when negotiating their place in the Canadian workforce. While Giulio's relative financial stability and lack of familial dependents afforded him a more attractive opportunity, others, such as Nelia and Omer, felt that so-called 'typical refugee jobs' prevented language development. Omer 
described RCs as falling in "a trap, between work and school for English", stating he often had to stop and start English programs as work became available. While quitting in order to work was acknowledged as hampering long-term success, passing on paid work was equally damaging to his independence and identity.

\section{Unrecognized Potential: the Devaluation of RC Human Capital}

Devalued educational and work experiences are long-established barriers affecting immigrants of all streams, and as this study indicates, RCs are no exception. Whether coming from a professional or skilled trade background, a total of seven participants, whose past professions ranged from university professor to land dispute mediator, stated their educational credentials went unrecognized in Canada, and not one participant was working in the same profession they were in at home. Echoing findings by Teelucksingh and Galabuzi (2005), participants' collective experience of demobilization understandably elicited feelings of frustration and powerlessness as they grappled with a declining professional status:

"I have two degrees for chef...but nothing from the past counts. Now, it is everything new. Only construction. It's hard". (Elias)

"I know I can give support to people [as in my former career]...but the problem isn't if you're able to do the job. The credentials, the background, that is what matters". (Bernardo)

\section{Nested Barriers: Blockades to Bridging and RC Volunteerism}

Facing the reality of their de facto uneducated, inexperienced status, many participants responded with great flexibility, quickly prioritizing financial demands in lieu of professional expectations in order to attain a 'survival' job as quickly as possible: "If I cannot find a job in roofing, I will work anywhere", stated Jon. Bernardo lamented 
the availability of only 'refugee jobs', a concept that will be explored in the 'Space Between': the Distinctiveness of RC Labour. "As long as I see I could work only in the cleaning area, or maybe in the construction area...sometimes I think, 23 years of experience for nothing here? It's frustrating."

However, while the reality of a devalued education is not unique to RCs, the barriers precluding them from bridging their credentials are. As non-citizens, four respondents - Adela, Flor, Elias and Lazar - stated they were unable to bridge their previous credentials because they were denied access to domestic tuition rates. These results echo findings by Coates \& Hayward (2005), who suggested credential recognition as effectively available to only permanent residents and citizens. As this study's participants also cited the ability to work in one's desired field as key to feeling "fully integrated", this structural barrier preventing credential recognition suggests RCs are at a greater disadvantage to integration than other newcomer streams, enhancing what Sawyer and Turpin (2005) describe as the impermanent feeling of being neither here nor there. Adela and Lazar also indicated heightened feelings of precarious impermanence as they remained in limbo, unable to begin working in their desired fields, unable to afford bridging, and fearing the inability to ever re-enter past professions.

However, gaining Canadian work experience proved somewhat feasible through the act of volunteerism. Participants described their often extensive volunteering- with one respondent, Nelia, logging over 3000 hours - as critical to gaining valuable Canadian work experience, confirming the findings of Krahn et al. (2005). Volunteering was also perceived as a way of re-enacting and re-claiming past employment-based identities, a concept that will be explored in Volunteering Time, Reclaiming Identities 


\section{The RC Status: Impermanence, Ascribed Identities, and Employability}

Evidently, RCs are faced by two formidable employment barriers, English abilities and credential devaluation, that are well established as barriers experienced by other immigration streams (e.g. Krahn et al., 2000, Beiser et al., 2000, Teelucksingh and Galabuzi, 2005). However, participant responses also suggest that the refugee claimant status poses additional and unique challenges to its bearers. The following section will note the unique challenges experienced by RCs as a result of their telling 900-series SIN card, their potential impermanence, and the negative connotations associated with the term refugee claimant, substantiating refugeeness as a barrier to employment.

\section{The 900 Series SIN: Marking 'Refugee’ and Limiting Employability}

It is interesting to note all participants described navigating the SIN and work permit application process as "easy" to understand and complete. However, as RCs' SINs begin with a 9 to denote nonpermanent status, issues with employers often arose, echoing the findings of Cholewinski and Taran (2010). Four participants, including Nelia, reported direct experiences of employer discrimination based on one's SIN number: "It marks, refugee, refugee, refugee. Somebody will see it and think, [not a problem] 'it's good, it's good'; but somebody else will see that and think 'no, many problems"'. Other participants stated they assumed their SIN "gave them away" as undesirable RCs, preventing them from attaining jobs. The SIN barrier was largely linked to indicating impermanence, a theme that will be discussed in greater detail.

All claimants were frustrated with the often long waiting period before attaining the necessary documents. As these long waits prevent entrance into the formal economy, it is possible this structural inefficiency is incentivizing working underground. Malik 
explained that, as a largely uninsured RC, he needed to begin working immediately in order pay for his medical expenses, and was considering working 'under the table' out of necessity. This discussion of cuts to the IFHP and refugee claimants' employability will be explored in Changing IFHP Policy and RC Employability.

\section{Impermanent Precariousness: Implications for Employability}

Despite being easily attainable, the 900 -series SIN number assigned to all RCs did pose a practical barrier because of what it implied: impermanence, and for some participants, perceptions of "unnecessary trouble" (Lazar). Seven respondents stated their status was regularly perceived as precarious or transient and thus, unattractive to employers. "It's really hard to work when you're a claimant, because it's not secure. You don't feel secure at all", stated Elias. Indeed, RCs are neither temporary workers, nor permanent residents, and instead straddle the precarious gap between citizenship and transience. Resultantly, RCs' employment experiences are underscored by the looming possibility of removal. Until full citizenship is attained, Dobson's refugeeness explains that refugees will continue to feel this impermanence as "compulsive migrants ... of sedentary strangeness, with the ever-present potential to move on again" (p. 16).

Flor noted the predictable trajectory of her status-related issues: "I'll get as far as the interview without having to reveal I'm a refugee claimant, but I always have to show it eventually, and it always hurts me". Employers do not trust refugee claimants, she explains, because of they do not know where they'll be tomorrow; "In a way, they're right. I am in limbo. I understand where they are coming from, I don't judge them.” This 
admission of empathy towards an employer's hesitation acknowledges the uncertainty of her situation, and the real limitations her status imbues.

\section{Ascribing Capabilities: 'Refugeeness' and Employability}

As mentioned, responses indicate that the RC label incites evaluative assumptions regarding participants' worth and capacity as workers, effectively limiting their ability to work in many sectors, including the oft-desired office jobs. Critically, responses suggest participants felt relegated to certain sectors within the Canadian workforce. "We are in some fields now that Canadians, they won't do", asserted Adele; "Cleaners, in farms, in factories, in lines of production, kitchen helper ...you will never see a Canadian person working such a job". Indeed, the phrase 'refugee jobs' was used to denote types of employment participants perceived themselves as employable in: physical labour, cleaning, and construction. The existence of 'refugee jobs' might then be understood as an aggregate of societal assumptions regarding what an RC is capable of. Carisa argued that employers assume that unlike immigrants, RCs are incapable of adapting: "They think the big difference between me and other immigrants", she asserts, "Is that immigrants can know the country, and how they do everything here."

While many participants experienced credential devaluation, responses also suggest that most often participants were assumed to have no credentials. That is, respondents reported that as RCs, they were assumed to be unskilled labour, despite the majority of this participant pool originating from a skilled profession. Resultantly, participants described a deep frustration towards these misperceptions, an anger further underscored by their language barriers: "I felt before, how do you say? Impotente. Impotent, powerless! I wanted to express myself, but I can't!" (Herminia). Indeed, all but 
three participants suggested their impermanence and RC label relegated them to certain positions in the Canadian workforce. This perceived incapability was compounded by further discrimination against their refugee status based on subjective understandings of the role of RCs within Canadian society.

However, although participants expressed frustration with this demobilization, the most frustrating aspect for many was not the new type of work they were employed in, but the variables that define it - precarious, impermanent, short-term, and for many, under-the-table. All but one participant reported finding only temporary, part-time or contract work despite remaining in Canada for many years. "People think RCs are just here for a short time," stated Inez, "but really, it could be for years and years". Herein lies the distinctiveness of refugees' labour market experiences; without the guarantee of a temporary or permanent stay, RCs' stay in Canada is awash with unknowns, which is reflected in their precarious and short-term labour market opportunities. However, the reality remains that RCs' stays in Canada are rarely short-term. CIC reports that the average $\mathrm{RC}$ remains in Canada for 1, 038 days, with some people remaining in limbo within the determination system for as long as ten years (CIC, "Backgrounder", 2012). Participants were largely able to acquire only temporary work, despite having arguably long-term employment needs. Participants described the cyclical nature of constantly starting new jobs as frustrating, and reported at times feeling overwhelmed by the stress of their ongoing job search, and not knowing if, and from where, they would be paid the next day. 


\section{Ascribing Identities: Negative Discourse and Employability}

Pozniak (2009) found Canadian immigration discourse to be comprised of "certain narratives that serve as conceptual templates, or lenses, for thinking about immigration and immigrants" (p. 188). Specifically, Pozniak finds the narratives of immigrant merit and immigrant cost instigate the 'good' and 'bad' immigrant dichotomy. These discourses shape how newcomers represent themselves, as they quickly understand "the acceptable language of representation", and then appropriate their own experiences to construct their self-representation as "good refugees" (p. 188). However, this study's responses suggest that RCs are not just aware of the 'bogus refugee' discourse, as found by Pozniak (2009), but also, encounter this narrative as a barrier to their employability.

Indeed, in addition to procuring assumptions about credentials and capacity, the mass equating of refugee claimant with bogus refugee and queue jumper creates an environment of cynicism and distrust towards RCs, and decreases their chances of attaining employment. Participants stated these labels permit and purport others to conceive of RCs as illegitimate presences within Canada and thus, the Canadian workforce.

Certainly, RCs are faced with the public narrative suggesting RCs choose unemployment, and resultantly, are economic drains to Canada; ironically, participants suggested this very discourse noting RCs' economic burden actually prevented them from finding a job. The circularity of this issue reinforces and reinvents the image of the bad, bogus refugee: "[The government] is creating a lot of divisions among Canadians, among people, with the terms 'bogus refugees"', articulated Giulio; these divisions play out in a dislike towards RCs, he suggests, "by using phrases like "why RCs get a benefit 
when the average Canadian taxpayer is not eligible for it? Of course, say it like that and anybody will agree". Respondents often referred with disdain to those who did abuse social services and welfare, supporting Pozniak's (2009) assertion that immigrants distinguish "good" immigrant discourse, and appropriate their experiences within this framework.

The link between generalized refugee discrimination highlighted in recent media and $\mathrm{RC}$ employability was recapitulated by Elias' recanting of the effects terms such as 'bogus refugees' have on the attraction of hiring a refugee claimant: "The employers prejudge the person", he stated; "It's in the lingo". This parallels a link suggested by findings in Making Ontario Home, which linked increased discrimination against RC to "the recent negative focus on refugee issues" (p. 73). Participant responses note the existence of the 'undeserving refugee narrative' as an additional unique barrier RCs must refute as they attempt to prove their value as both workers and future citizens:

The people think, 'oh it is a new idea for immigration, we will have better immigrants to improve the economy'. That is the side they are showing; one of the ideas they are working on not so openly is that $R C$ are a problem area for taxpayers. That is not true. I hear people, "oh the refugee claimants, they cost in health, they cost in welfare!' But most of the refugee claimants are people who are working hard. As I saw, the government is not presenting directly that situation [the cost of refugee claimants] but is softly, softly showing that because when you are implying something sometimes, you are very more effective than when you are simply saying. (Bernardo)

Li (2003) echoes Bernardo's concerns, and argues the very term refugee implies an unsolicited immigrant who will be a "burden to the state, since their successful integration to Canada is seen as depending on the state's capacity to provide adequate settlement" (p. 47). Li's explanation illustrates the impact ascribed identities can have in limiting RCs' employability, and the powerful, emotive role phrases such as refugee 
often play in shaping refugeeness. Dobson (2004) furthers this, and suggests these powerful biases and assumptions towards RCs that form to create ascribed refugee identities are often an aggregate of personal biases and media coverage. Responses indicate these changing discourses made employers hesitant to hire RCs as they questioned the legitimacy of RCs within Canada, and viewed them as "waste of the taxpayer's money" (Malik). Lazar, a claimant from Hungary, stated he felt tension when people knew he was a Roma RC:

I think the government, they are so discriminatory about refugees and mostly about Roma people. I don't think the Canadians even knew about so many stereotypes until the government told them all these things. The newspapers, the everything...sometimes I look at it and I think, oh it is just like at home...Applying for things is the only time you feel bad, feel bad about being in Canada and what is happened. Someone saying no because of what you are - at home Roma, here refugee. I felt so, so bad. My brain, my heart, felt so, so bad after that. I felt like, what can I do though? What can I do?

Lazar's belief that negative refugee identities are created in government discourse and then ascribed to RCs stems from multiple encounters of his RC status as a barrier. Preventing employment perpetuates RCs' feelings of impermanence and precariousness, inhibiting these potential citizens' ability to integrate and maintain a sense of independence during these tumultuous life changes.

\section{The 'Space Between': the Distinctiveness of RC Labour}

As with many migrants, RCs often work in jobs that are "dirty, dangerous, and demanding” (Lenard and Straehle, 2010 p. 283). However, as previously mentioned and further denoting the distinctiveness of $\mathrm{RC}$ experiences, participant responses suggest the $\mathrm{RC}$ status and ascribed refugee identities leave RCs perceived as capable for only the least desirable of these decidedly undesirable jobs. Bauder (2006) observes that both 
migrant and immigrant workers often work "at or near minimum wage, in unstable jobs, and without the proper enforcement of labour standards" (p. 20), factors that certainly true for RCs, despite being legally permitted to work. Ascribed identities, expectations of which positions RCs ought to be satisfied with, and the tangible repercussions of precarious status render RCs perceived as "suitabl[e] for some occupations", such as disposable, short-term positions, "but not for other occupations" (Bauder, 2006 p.88).

This, explains Bauder (2006), is the working of a two-tiered labour market that continually relegates immigrant and migrant labour as secondary. Drawing on the work of both Marx ([1867] 2001) and Piore (1979), Bauder (2006) illustrates how migratory labour supplements and supports a host country's labour market. The labour market is divided into two segments: the primary segment, which contains desirable, skilled positions, and the secondary segment, containing undesirable jobs that are largely responsive to "cyclical slowdowns" (Bauder, 2006 p. 20). The employing of migrant and immigrant labour in the secondary labour market segment facilitates nonmigrants' ability work in the primary segment. By filling undesirable jobs that hold little security, migrant labour effectively "enables the nonmigrant population to escape being used as expendable labour in the secondary labour market" (Piore (1979) quoted in Bauder, 2006 p. 20).

However, it is difficult to conceive of RCs as immigrant or even migrant labour, as RC flows do not respond to a labour market's needs or cycles. Unlike the more than 186, 913 economic class immigrants and 182, 276 TFWs who entered Canada in 2010 (CIC, Annual Report to Parliament, 2011), RCs are not recruited for labour, and are not drawn to Canada for its potential economic prosperity. Resultantly, RCs' labour 
experiences cannot be neatly categorized as similar to either immigrants or TFWs. Instead, their experiences are comprised of objectionable labour characteristics from either stream, and then underscored by the unease of impermanence. Neither temporary nor permanent, $\mathrm{RC}$ labour can then be conceived of as occupying the space between other streams' labour market experiences, approaching and experiencing employment differently. This is not to imply RCs are inherently worse off than other migrants, but to acknowledge the uniqueness of RCs' labour challenges.

Certainly, RCs' employment barriers echo those of recent immigrants. For example, skilled immigrants also earn less money for more educational attainment (Reitz, 2001), and are routinely 'deskilled' through a devaluation of their employment history (Bauder, 2003). However, as noted Nested Barriers: Blockades to Bridging, these barriers are often exceedingly more difficult to overcome for RCs. Unlike immigrants, RCs often flee their country with little time to assemble credential documents (Coates and Hayward, 2004), only to be virtually barred from credential bridging because of international tuition fees. Without the guarantee of permanency, RCs are limited in their ability to personally invest in overcoming these barriers. The result is RCs taking the most precarious of undesirable work, often working in the informal economy despite holding work permits.

Correspondingly, RCs' employment experiences also share similarities with TFW. For example, both are subject to exploitation by employers, often in physical labour positions (e.g. Lendard and Straehle, 2010, Golding, 2010). In addition to working long hours for little pay however, RCs rarely have any guarantee of continual work, and are 
rarely under a formal agreement with an employer. Instead, RCs often fill very shortterm, transient positions, with little assurance of rehire the next day, likening their experiences to those of undocumented workers, despite holding work permits. Katia, Omer, and Elias suggested it was not uncommon to work long hours for less pay than was promised, only to be told there was no work the next day. Despite work permissions, several participants were told by employers they would be hired only if they accepted cash, and thus, the exploitive conditions that accompany it. The uncertainty of their labour market position reflects the uncertainty of the refugeeness experience, and leaves them vulnerable to employer exploitation.

Evidently, despite sharing similar employment experiences, the critical distinction remains: unlike immigrants, TFW, or often, undocumented persons, RCs do not enter Canada to find employment. RCs are not economic migrants, but individuals fleeing persecution that do not choose to become refugees but rather, are forced (Chimni, 2009). However, while employment is not the reason for entering Canada, upon entry, find a job becomes critical. Primarily, RCs must work in order to make money. In addition to the cost of living, participants noted additional high costs experienced by $\mathrm{RCs}$, such as paying a minimum of $\$ 550$ for $\mathrm{H} \& \mathrm{C}$ applications, or covering the cost of medical bills (CIC, “The Refugee System”, 2012). Should RCs be successful in finding a job, albeit most often temporarily, they may begin to address secondary goals, such as maintaining independence and identity during a tumultuous and uncertain period in their lives. These themes will be explored vis-à-vis RCs' labour market experiences in the following section. 


\subsection{The Distinct Experiences and Expressions of RC Employment}

While RCs face unique employment barriers, they also experience employment uniquely. Responses suggest RC belonging and integration is facilitated by employment, which allows RCs to not only participate in, but also give back to greater society, an action deemed highly important by participants. The following section explores the many meanings participants assigned to the concept of employment, as well as the role employment plays in shaping refugee identity and defining one's refugeeness.

\section{Employment as an Expression of Citizenship}

While eleven participants predictably stated financial necessity as the prime motivator behind employment, responses also indicate that working procures many important non-financial benefits for RCs. Notably, the act of 'working' was described by thirteen respondents as critical to enhancing other areas of life associated with citizenship, such as meeting and befriending other Canadians, practicing English, and as evidenced by Jon and Malik, putting down roots to combat feelings of transient impermanence:

So when you're not working, it's really hard you know? You feel like you are not a Canadian. If you working with everybody, actually you meet people, and [they] help you with English and everything. But without working, it ain't like that. It'll be okay when I work, but before that, no (Malik).

When you start to work, you are living here. You have to go to work, so you feel more in the home, like you are doing something (Omer).

Drawing on the notion of identity construction and renegotiation, Létourneau (2001) explains that "there is a very deep ontological longing in people to feel complete, which manifests itself in a desire to belong to something that is greater than oneself' ( $p$. 5). Responses suggest that belonging to something that is greater than oneself includes 
participating and integrating in Canadian society, something participants stated was only fully possible should one be employed. Defining 'integration' from an economic perspective, Bauder (2006) asserts, "integration means that immigrants have a distinct economic function that is vital for local, national, and international economies to operate" (p. 9). However, responses suggest that in addition to allowing RCs to integrate economically, employment also acts as a catalyst to integration in an almost cultural sense. Employment and all its factors - being paid, maintaining independence, and paying taxes - help one "feel like a Canadian", stated Carissa.

This expands upon findings by Manjikian (2010); in examining the indefinite period between one's refugee claim and IRB hearing, the author focuses on "the realm of social inclusion... where the actions and the notions of civic participation start to develop within the new urban dwelling" (p. 51). These findings indicate that RCs feel a part of "the realm of social inclusion" by experiencing the non-financial, secondary benefits to employment, suggesting employment is not just a manner of attaining economic integration, but a vessel towards social inclusion.

Indeed, responses indicate that employment is strongly associated with feelings of "giving back to Canada" (Inez and Malik), both as a symbolic gesture of indemnity and through the tangible act of paying income taxes. Several participants stated that employment is representative of the RC's desire to integrate. Bernardo stated that although RCs face many employment barriers, "What I do know is if a refugee claimant can work, he is able to reveal a new life faster, and to give back to Canada instead of being a charge for the taxpayers". Flors echoed Bernardo's belief in the symbolic power of a working refugee claimant, stating, "I think it will help you get accepted [by 
Canadians] because they will see you are not relying on the government and not taking from them".

Indeed, employment's often-abhorred tenant - taxation - was described, rather unpredictably, as a desirable expression of citizenship. Several participant responses suggested this oft-beleaguered landmark of the Canadian welfare state to be an indispensable, almost performative act of the much sought after citizenship. "We know, we need to study", stated Inez; "why? To get better jobs. We get a good job, we're going to make good taxes for the government. Cause that is important here." In this sense, working becomes an almost cultural ontological experience, facilitating integration by including RCs in Canada's interwoven economic and social networks, while allowing them to "give back" through working commitments and taxation. For people whose primary goal is attaining citizenship, the integrative factors associated with employment cannot be understated.

Similarly, paid employment is highly valued by RCs because it is perceived as a manner of setting down roots and countering feelings of impermanence stemming from their precarious status. Nelia found employment to be important symbolically, not only because facilitates participants feeling like financially contributing members of Canadian society, but because it "puts [RCs] in the system". However, for Omer, working may often be symbolic of 'giving back', but did not necessarily translate to feeling socially included. He asserts that the types of positions most commonly held - that is, 'refugee jobs' - may actually act as a barrier to integration given the often long hours and unpredictable schedule: "But how can these people increase ... their level in Canada and learn about Canadian culture and their education if they are working as dogs all the time? 
It's crazy", he asserted. Arguably then, striking the right balance in order to maximize the use of employment as a integrative tool may depend on attaining a job conducive to such integration, an attainment participants suggested was mainly facilitated by "getting papers"- that is, being accepted at the IRB and becoming a permanent resident.

\section{Employing, Engaging and Re/Defining Identities}

\section{Volunteering Time, Reclaiming Identities}

Building again on Létourneau's (2001) assertion that identity can be solidified via belonging to something that is greater than oneself, volunteerism proved to be a manner for RCs to re-involve themselves in their past professions and thus, their past identities. Indeed, in addition to volunteering in order to gain Canadian experience, four respondents from regulated professions reported volunteering in their field. Participants stated that volunteering allowed them to not only remain engaged in their professions, but to maintain and reenact a core component of their identity. While Lacroix (2004) found former professionals wary of volunteering in their field for its lack of perceived benefits, this study indicates participants often volunteered directly in their professional domains, or, donated time to fields that allowed them to recreate the most loved aspects of their prior professions. Adela, a professor in El Salvador, described recreating such components by volunteering in a local youth shelter; "I like to be around young people; that's why I was a teacher. That was a really good time". Like other participants, Adela experienced downward mobility as she shifted from college teacher to kitchen helper; volunteering was enjoyable for her, she explained, because it allowed her to reignite a piece of her identity she thought had been lost due to credential devaluation. 
Amundsen (1994) finds that while identities are constantly renegotiated at all stages of life, identity determination "becomes particularly significant during times of transition when boundaries are fluid" (p. 99). In particular, the author notes, "[t]he interplay between self and the labor market forms the nucleus of identity negotiation" ( $p$. 100). Evidently then, being unable to find desirable employment, let alone employment for which they are trained as a result of one's RC status, may negatively impact RCs' identity renegotiation at this especially tumultuous period in their lives. However, as these responses indicate, a loss of employment-based identity may be countered through volunteering, which assists RCs in reconstructing key identity narratives.

Similar to Adela, Omer described his attempts to volunteer as a Spanish teacher in Toronto; a former ecology professor, he hoped this would help prevent skill erosion. Likewise, former attorney Giulio perceived volunteering in a legal office as critical to his understanding of the nuanced Canadian legal profession: "Through this volunteering I've been doing, I get in to the places I want to be. For example, I'm not a lawyer here so I can't get the same access except through the volunteer"1. Evidently, when credential devaluation barred participants from their regulated professions, volunteering became a means of access. These responses may indicate that participants viewed their professional associations as strong components of their cumulative identity. These acts of volunteerism engendered a sense of belonging within the community, and combatted RCs' sense of "suspended temporality" (Manjikian, 2010 p. 54).

Interestingly, for some, the refugee determination process itself became a site of identity renegotiation. While the determination process is undoubtedly a long and

\footnotetext{
${ }^{1}$ Notably, as a permanent resident, Giulio was accepted to a Canadian law school, and delayed his admission in order to continue his volunteering. He perceived this volunteer work as integral to both improving his English skills and attaining a more holistic understanding of the Canadian immigration system, his chosen specialization.
} 
arduous process for all those who pass through, three respondents felt navigating the refugee system initiated a shift in their values and a re-prioritizing of what they perceived as necessary to their work identity. "After going through the refugee process, I really wanted to work with people", recalled Giulio; “[b]ecause my life changed, and my values and concept and point of view had changed since I was an immigrant and since I passed through the system". This participant, along with Elias and Herminia, stated they wished to enter the legal profession to assist others who had been in similar situations.

\section{Government Assistance and Identity: 'Welfare' and the Refugee Claimant}

"Welfare? No. No! It is better to work for so many reasons - more money, you don't feel uncomfortable, and you are knowing more Canadians. So I know having a job is good for me for so many reasons" (Jon)

"It's simply contradictory to think that a RC is coming here because of the generosity of the social benefits." (Giulio)

In line with findings by Pozniak (2009), discussion of government assistance provoked responses indicating participants' strong desire to distinguish them from the evidently pervasive bogus refugee stereotype - that is, a RC who enters Canada, often illegitimately, only to immediately forgo work for welfare. Resultantly, all participants interviewed indicated a fierce desire to become financially independent through gainful employment, and moreover, to no longer rely on the Canadian government for assistance. Certainly, while demobilization and the loss of professional identity associated with 'refugee jobs' were described as disempowering, claimants overwhelmingly indicated their preference to attaining a 'refugee job' over accepting government assistance, which was described with disdain and embarrassment:

I was on welfare for a short time but only because I had to be. I didn't want to be. When I was on welfare ... being on welfare ... it is uncomfortable. It makes me so 
uncomfortable. I want to live on my own, not live on the government. But I had no choice, because I couldn't sleep outside, I had to eat something." (Lazar)

In these instances, participants again reported encountering an ascribed identity regarding RCs' perceived cost in - and implicitly, undeserving usage of - government assistance, a stereotype respondents perceived as contributing to the overall distrust of RCs, and negatively affecting their job search.

Certainly, although it is not within the scope or implicit purpose of this study to hypothesize why recent discourse has framed RCs in a decidedly negative light, it is interesting to explore the public construction of the RC identity vis-à-vis welfare use, as this concept emerged from participant experiences. Interestingly, the negative impact bogus refugee discourses and perceived assumptions of welfare abuse is well theorized through an analogous comparison with the notorious 'Welfare Queen'. 'The Welfare Queen' stems from 1960s racialized, politicized discourse. This discourse is embedded within a period of welfare reform, and symbolizes how a constructed image - in this case, of fertile, poor, African American women - can be sensationalized in the media and used to justify dramatic policy reform that directly affects this Other (Zucchino, 1997).

Ange-Marie Hancock (2004) finds that this Welfare Queen's identity hinges on her supposed, contemptible use of social benefits. Hancock explains that the Welfare Queen image was created through a combination of emotional responses towards public representations of poor African-American mothers, and a 'public disgust' regarding their mythical welfare abuse and fecundity. These factors interacted to create the concept of the black 'Welfare Queen', a woman who had many children for the sole purpose of cheating the system. Radical economic social reform is predicated on society analogizing welfare use with 'others' abusing the state purse, or as Dionne (1996; quoted in Peck, 
2001) observes, associating welfare with "dependency, sloth and illegitimacy" (p. 208), These associations created a reified image of the welfare user rooted in overtly racist assumptions towards black mothers, and used to justify attempts at radical American welfare reform in 1996.

Although not equivalent, the concepts 'Welfare Queen' and 'bogus refugee' may be conceived of as conceptually analogous for similar invocations of illegitimate welfare users to justify and substantiate substantial policy reform ${ }^{2}$. As with the Welfare Queen, emotive and negatively framed events, such as the aforementioned various boat arrivals, elicits emotional responses towards RCs as queue jumpers, and questions their place within society. These emotional responses interact with public and media scrutiny focusing on RCs' apparent high costs and welfare use to create and perpetuate a negative refugee claimant identity - that is, the bogus refugee. This discourse then permeates public opinion, which then becomes public consensus. This cost and merit-based narrative as who is entitled access to the state's welfare system and implicitly, the Canada's refugee determination system, is then used to justify and substantiate radical refugee reform. Moreover, as this study indicates, this pervasive public narrative affects not just policy reform, but also creates an environment of distrust that translates to employers' reluctance to hire. Indeed, this conceptual analogy illustrates how powerful discourses evoke change in public perception and subsequently, refugee claimant participants' chances of finding work.

\footnotetext{
${ }^{2}$ Although the author is drawing on the experiences of African American women in America, this is arguably also the case for RC in Canada. Certainly, one might state Canada's political climate - that is, the welfare state - is starkly different from that of America and thus, an analogy suggesting disdain towards welfare users does not hold. However, I contend that as outsiders, as non-citizens with precarious status, refugee claimants are subjugated to the same definition.

${ }^{3}$ Current unprecedented refugee policy reform is discussed in Protecting Canada's Immigration System Act and IFH: an Overview.
} 


\section{Reduced Healthcare, Reduced Employability?}

\section{Protecting Canada's Immigration System Act and the IFHPP: an Overview}

Protecting Canada's Immigration System Act, or Bill C-31, was granted Royal Assent on June 28, 2012. Included in its myriad of reforms were key policy changes specifically affecting RCs, including reduced determination timelines. At the same time, the federally funded Interim Federal Health Program (IFHP) underwent equally notable reform. Prior to recent reductions, the comprehensive IFHP offered uniform health care coverage to all refugees. For successful refugees, this coverage extended until their health care costs were transferred to provincial governments. For failed claimants, this coverage lasted until their removal order came in to force. Study participants who raised IFHP cuts as an area of concern had all experienced reduced health care coverage upon the implementation of IFHP reductions on June 30, 2012. Despite initially receiving comprehensive preventative and emergency care upon their arrival in Canada, concerned participants - all current or failed refugee claimants - received notice from CIC in May, informing them of their newly reduced health care coverage ${ }^{4}$.

Current refugee claimants can now access preventative care only if their ailment is a public health risk, and cannot access hospital services except in emergency situations. Failed refugee claimants receive less health care coverage as they are permitted access to preventative or emergency medical services only when public health or safety is at risk (CIC, "Interim Federal Health Program" 2012). This research indicates that IFHPP reductions may not only compromise affected persons' access to health care, but also, their employability.

\footnotetext{
${ }^{4}$ This information was found on a CIC Call Centre IFHP information recording on September 10, 2012.
} 
However, should the reduced refugee timelines detailed in Bill C-31 be enacted as currently outlined, it is important to note that RCs' ability to attain formal employment will be virtually eliminated. Indeed, CIC (2012) states that under the new refugee determination timeframe, RCs will remain in Canada for a maximum of sixty days prior to their determination hearing, and at very most, a total of 216 days if all appeals are exhausted ("Backgrounder: Summary of Changes", 2012). In addition to time needed to both navigate the system and find a job, attaining a work permit and SIN takes an average of over two months; under these reforms, RCs will be effectively barred from formal employment. This may force RCs to work in solely in the informal, unregulated, and untaxed economy. However, while IFHP-based employment barriers may potentially affect RCs only until Bill C-31's new timelines are enforced, these barriers are profoundly injurious, and ought to be noted as affecting potentially thousands of current RCs, as well as failed RCs whose removal order has yet to come in to force.

\section{Changing IFHP Policy and RC Employability}

As the aforementioned subjectivities suggest, RCs are often assumed to be without agency, and are presented as passive actors within the refugee determination process (Manjikian, 2011). However, findings from this study suggest the reverse to be true. Participants held a comprehensive understanding of their location within current policy change, with seven participants broadening the depth of this study's discussion on

policy by noting the specific impact change to the Interim Federal Health Program (IFHP) may have on their employability, an important and yet unexplored topic with real consequences for this study's participants. Respondents raised five areas of key concern: 


\section{RCs may no longer feel "safe" working in conventional refugee jobs:}

As previously discussed, all but one of this study's participants was employed in a 'refugee job' - construction, cleaning or physical labour. Three participants, Bernardo, Elias and Omer, indicated that given the high-risk nature of many refugee jobs, full medical coverage was a necessary consideration, and reductions to the IFHP may compromise their ability to continue working. Elias, a failed RC currently preparing to apply for $\mathrm{H} \& \mathrm{C}$ consideration, would have previously received coverage under the IFHP as he was still legally permitted to remain in Canada. However, under the new considerations, failed claimants will have access to emergency care "only if needed to diagnose, prevent or treat a disease posing a risk to public health or to diagnose or treat a condition of public safety concern" (CIC, "Interim Federal Health Program" 2012). As Elias is often only able to attain higher-risk construction jobs, Elias expressed great concern for his future: "Without insurance, it is so dangerous for me to work in construction, in roofing because I can't afford the hospital. I need to be more careful because my girls don't have nobody else, but I need to work cause what else am I going to do?"

\section{Employers may be less likely to hire RCs without full health insurance:}

Under the new IFHP revisions, failed RCs and people from DCO no longer receive any health care coverage unless their condition poses a public health risk. While the DCO has not yet been published, Adela echoes the concerns of many refugee advocates (e.g. Canadian Council for Refugees, 2012) who fear her nation of origin, Mexico, will appear on this list and she will soon lose all healthcare coverage unless her 
ailment is a threat to public safety (CIC, "Interim Federal Health Program" 2012). Adela noted the newly tiered health care coverage categories to be very confusing, and importantly, believed that employers will be unable or unwilling to distinguish which refugee streams are eligible for which type of coverage. Fearing liability or the need to pay for private insurance, employers will be increasingly reluctant to hire any refugee claimants, who employers will perceive as high-risk, asserted Adela. "And so employers are thinking if something happened with that person I would have to pay for that because the government is not responsible any more", she feared.

Rather than be faced with a situation of an injured and uninsured employee, Adela predicted, RCs will simply no longer be hired. With reduced employment chances and increased expenses through uninsured medical bills, Adela feared refugee claimants would be in a state of, "less than poverty. Poverty will be here, and people... will be even less than the poverty level, like refugee claimants. It will be misery".

\section{The federal government is "not holding up its end of the bargain":}

As explored in Employment as an Expression of Citizenship, the act of paying taxes was viewed almost ceremoniously, a surprising but understandable act in affirming one's place in the workforce. However, as an $\mathrm{H} \& \mathrm{C}$ applicant, Nelia noted that taxation as "an act of citizenship" still runs two ways, and one is entitled to the services they pay in to. Through her cleaning position, which she had held for a number of years, she noted she paid taxes on her income: "Yes I pay the taxes, [because] I need in different situations the government's help - taxes are good, it's good for the people, for the government, if you need". However, despite years of taxes deducted from her 
paycheques, presumably to cover programs such as the IFHP, as an H\&C applicant, she is now excluded from its benefits, having received a notice from CIC in May of her reduced IFHP coverage: "Because the government, in my case, government pay for me and medicine, but at this moment, refugee no! Any problems with the persons, it's up to them!" Visibly frustrated, she viewed the Canadian government as no longer honouring their commitment - she pays her taxes, but necessary healthcare services will no longer rendered. This parallels the situation experienced by TFW. Despite paying taxes, TFW cannot access unemployment insurance or pension plans; paralleling the new situation of RCs, TFW are also barred access to healthcare outside of emergency services. Lenard and Straehle (2010) state almost in jest that despite paying taxes, these services "are often denied to temporary workers, on the grounds that they are, after all, only temporary" ( $p$. 288). If we are to accept Lenard and Straehle's facetious explanation as just, than this justification still cannot apply to RCs, who as previously noted, are not necessarily temporary. Evidently, under changes to the IFHP, RCs will be subject to the same unjust taxation as TFWs through both income and consumption taxes.

Similarly, Omer felt structural barriers enacted by the government, such as delayed work permits and 900-series SIN cards, force RCs and other precarious workers to accept unsafe work out of necessity. This incentivizing of work in the informal, unregulated economy is made even more dangerous with the reduced medical coverage for RCs, who Omer feared would be confused by the complex new healthcare arrangements, and would not access any services out of fear of being charged. "The government say, okay it's good that people work, we need them to work but they don't create the conditions that people need to work confidently", stated Omer; "Then they say, no healthcare. ... And it's crazy. 
The government is so blind that they don't see this."

\section{Without medical insurance, the need to find gainful employment takes on heightened urgency:}

Malik, a 29-year-old male from Turkey had arrived just two weeks prior, and had recently been turned away by a doctor. "I want to get help because the federal government, they change the rules for health care? I can't go to doctor...I came here as a refugee and I don't have money to pay for it", he recalled. The importance of securing a paying job subsequently became even more urgent as he needed to begin immediately earning money in order to cover his necessary medical expenses. However, Malik was angered to learn that the requisite work permit and SIN might take several months to receive. His immediate application for a work permit reflected the urgency of his situation: "I'm looking for a job. I want to find as soon as possible because I want to pay my medical expenses", he stated, "It is more important now to find a job because I need to pay for health, for doctors ... If you don't have coverage, it's very hard". Malik hypothesized the long periods of time waiting for permissions may incentivize 'working underground' for refugee claimants who need to access preventative healthcare immediately.

\section{Issues surrounding RCs' inability to medications may also affect employability:}

Adele noted that not only are 'refugee jobs' high risk for sudden injury, but may also lead to long-term, repetitive injury, as well mental health issues deriving from stress and often, discrimination. She described the pain caused by her job as a kitchen helper: 
It's different than what I used to do in my country; it's very tired work. I like to cook, at the same time I didn't used to work that kind of job so now it's tired, and I have pain in my arms and my back. That's why I'm taking medicines. I have to chop all day so my arms, and my shoulder.

Without medication coverage under the new healthcare plan, she feared she would no longer be able to handle the physical pain associated with her position:

I'm now so sad, especially when someone asks you - how are you, how are you feeling? I cannot say I am fine, because I can't get any sickness [because of recent cuts to the Interim Federal Healthcare plan], and I don't know if I'm going to lose my job because of my status ... It generates anxiety, lack of sleep, everywhere; they say why are you sleeping? I say just to close my eyes and forget for one minute.

Evidently, participant responses indicate that the pending changes to emergency and preventative healthcare coverage may affect RCs' ability to be safely employed, or to be employed at all. Despite the possible repercussions to RCs' employability, the need to work becomes even greater in order to cover healthcare expenses. This is the 'Catch-22' of healthcare and employment; RCs need to work in order to afford adequate healthcare coverage, yet with their current inadequate coverage, participants stated they no longer felt safe working in these often-high risk positions. Despite cuts to the IFHP being enacted largely as a cost-saving measure (Fitzpatrick, "Refugee health wrong priority" 2012), this study indicates the IFHP cuts may present additional barriers to refugee claimant employability, potentially increasing the number of RCs requiring government financial assistance, while fewer RCs contribute via income tax.

\section{Section Four: Conclusions}

This paper has explored how the process of becoming a refugee - that is, refugeeness - substantiates RCs' employment experiences, and shapes their labour market 
outcomes. This research demonstrates that RCs' employment experiences during this time of "suspended temporality" (Manjikian, 2010 p. 54) are distinct, and framed by unique barriers stemming from the precarious RC status. Notably, several conclusions can be drawn from this research:

\section{Refugee Claimants' Precarious Status Creates Distinct Employment Barriers}

Using the concept of refugeeness to theorize RCs' subjective employment experiences, this paper finds RCs encounter formidable and unique barriers to employment and relatedly, integration. Findings suggests that while RCs face barriers similar to those of other newcomers, such as English proficiency and credential devaluation, claimants experience pronounced hardship in overcoming these barriers, as RCs are virtually barred from bridging educational credentials. Unable to access domestic tuition rates, RCs are faced with staggering international student tuition costs, rendering bridging nearly impossible. The uncertainty as to whether RCs will remain in the country compounds this problem; in the sole case of one participant, Giulio, being able to afford credential bridging, he was hesitant to do so because of the uncertainty surrounding his stay in Canada.

Participants reported the RC status and relatedly, negative RC discourses, were instrumental in inhibiting RCs' labour market successes. Specifically, the RC status presented barriers because of its implied impermanence. Findings suggest that employers are often unwilling to invest resources into hiring RCs, as their length of time in Canada is unknown. As a result, all except one participant reported finding only 'refugee jobs' undesirable temporary, part-time, or contract work that provided for only short-term 
needs, despite most participants remaining in Canada as RCs for many years. Participants felt RCs are perceived as uneducated and incapable, creating frustrations greatly compounded by initial language barriers. Relatedly, participants often left ESOL courses for short periods of time because of temporary work opportunities. These disruptions in learning inhibit RCs' ability to learn English, and further limit possibilities for long-term employment success.

\section{Negative Refugee Discourses Shape Refugee Claimants' Employment Experiences}

Additionally, findings suggest the prevalent 'bogus refugee' discourse creates a hostile environment of distrust towards RCs, engendering a sense of difference towards RCs and limiting their ability to find work. The 'bogus refugee' label and its pervasive assumptions regarding RCs' high cost and propensity to abuse the welfare system cast doubt on RCs' legitimacy and cost within Canada, and rendered them less attractive to employers. These narratives also enforced assumptions about the 'place of refugees' within Canadian society, including which jobs refugees ought to accept. Participants' notable awareness of RC discourses also indicates a high degree of media literacy among RCs, challenging the stereotype of refugees as passive or uninvolved (Manjikian, 2010).

\section{Employment: an Integrative Expression of Citizenship}

While receiving government assistance was described as an undesirable embarrassment and associated with feelings of powerlessness and dependency, employment proved to have various integrative social benefits for RCs. Indeed, while

participants expressed frustration over their seemingly unconquerable downward 
mobility, working in even 'refugee jobs' facilitated a sense of independence, control, and agency over their decidedly uncertain lives. In this sense, findings indicate RCs view employment as not only a necessary means to a financial end, but as an expression of citizenship. Being employed led RCs to feel as contributing members of society who were not only avoiding "living off the government", but "giving back" to Canada in the form of income taxes.

\section{IFHP Policy Reforms May Further Hinder Refugee Claimants' Employability}

In light of recent reductions to the IFHP, several additional barriers to employment stand to be noted. Participants expressed fear that employers would be less likely to hire RCs if they were perceived as having inadequate health care coverage and thus, a liability. Bernardo pointedly acknowledged that although the remaining IFHP is nuanced, and some refugee streams remain covered, understanding these nuances is difficult, and employers may be more likely to "not bother with refugees at all". Similarly, participants - especially failed claimants and those from countries feared would be on the DCO, such as Mexico - were concerned with their ability to keep working should they lose even their emergency medical coverage. As 'refugee jobs' are often dangerous and difficult, without full healthcare coverage, some participants in highrisk industries such as construction were concerned with their ability to continue working. 


\section{Study Limitations and Future Research}

As demonstrated, RCs' precarious citizenship status has emerged as a preeminent barrier to gaining employment. In order to fully explore the impact of this concept, as well as due to time and space limitations, other critical perspectives remained unexplored. Importantly, this study lacked a racialized or gendered analysis of findings. Key studies that take this approach ought to be noted, including Teelucksingh and Galabuzi (2004) for its discussion of racialized outcomes of institutional barriers, and Itzigsohn and Giorguli-Saucedo (2005) for its comprehensive gendered analysis of immigrant labour market incorporation. However, this study's analysis suggest RCs' distinct labour market barriers indicate the need for specific and targeted responses to these barriers, including a need for settlement and employment agencies to acknowledge the unique challenges faced by RCs.

As this study examines the experiences of refugee claimants during a time of unprecedented refugee policy reform, further research exploring $\mathrm{RCs}$ ' labour market experiences after the full implementation of Bill C-31's reforms is necessary in order to gain a more thorough understanding of RCs' employment experiences. Furthermore, as RCs' employment may stand to become a thing of the past, this future research would also create a benchmark unto which this study's findings might be compared, including the effectiveness of employment as an integrative tool for these potential citizens.

\section{Concluding Remarks}

Cresswell and Merriman (2011) argue, “[p]aradoxical subjectivities correspond with paradoxical geographies"; certainly, this rings true for participants. As neither 
temporary workers nor permanent residents, participants' unique and often exceedingly difficult experiences with refugeeness are noted. These experiences, including language issues, impermanence, bogus labels, and devalued credentials, compound and conflate one another, creating an intersectional and intertwined Gordian knot of employment challenges. Importantly, RCs perceive this knot of barriers as preventing and guiding employment experiences, and as divisible only upon attaining citizenship: "If I had the papers, I would have a good job," argued Elias; "Everything would be good. Because I am a worker, I am a fighter. The only thing stopping me is the papers". Indeed, in the eye of RCs, the desire for citizenship and all it is perceived to entail - economic and social integration, belonging, and permanence - justifies the often difficult experiences of refugeeness, and in the end, remains RCs' ultimate goal. However, in true Gordian tradition, the arduous process of refugeeness may prove indelible, continually marking employment experiences even after citizenship is attained, effectively perpetuating and prolonging RCs' place in the space between. 


\section{Appendix A:}

\section{Interview Guide}

\section{Demographic Questions}

1. Please state your name, age, and current citizenship status.

2. Where are you from?

3. When did you arrive in Canada?

\section{Core Interview Questions}

1. What job did you hold at home?

a. What about this job did you like?

2. In which fields/positions have you worked as a RC?

a. How did you find this job?

b. What was the job search like? How did you get a work permit and SIN?

3. Why is working important to you?

4. Would you consider, or have you ever, used government assistance?

5. What is the biggest barrier to finding a job?

6. What does it feel like to be a refugee claimant looking for a job in Canada?

7. How does working making you feel as a RC in Canada?

8. Do you think Canadians mind hiring RCs?

a. Do you show your SIN card when you apply for jobs?

9. Do you know about the changes to the IFHP and how this will affect RCs? 


\section{References}

Ali, M., Kobayashi, A., Cliff-Jungling, S., Ochocka, J., Lomotey, J., Araujo, L., et al. (2012). Making Ontario Home. OCASI. Retrieved July 25, 2012, from www.ocasi.org/downloads/OCASI_MOH_ENGLISH.pdf

Amundsen, N. (1994). Negotiating identity during unemployment. Journal of Employment Counseling, 31(3). Retrieved August 11, 2012, from http://mcgill.worldcat.org/search?q=Negotiating+Identity+During+Unemploymen $\mathrm{t}+\% 2 \mathrm{~B}+$ amundson\& $\mathrm{t}=\mathrm{owc} \_$search\&scope $=2 \&$ oldscope $=\&$ find $=$ Search

Archer, K. \& Berdahl, L. (2011). Observing the Political World: Survey Research. In Archer \& Berdahl (Eds.), Explorations: Conducting Empirical Research in Canadian Political Science (pp. 178 - 192). Don Mills, Ontario: Oxford University Press.

Bauder, H. (2003). Brain Abuse, or the devaluation of immigrant labour in Canada. Antipode, 35(4), 699 - 717. Retrieved February 1, 2012, from http://resolver.scholarsportal.info.ezproxy.lib.ryerson.ca/resolve/00664812/v35i0 004/699_aotdoilic

Bauder, H. (2006). Labour movement: how migration regulates labour markets. Oxford: Oxford University Press.

Bauder, H. (2008). Dialectics of humanitarian immigration and national identity in Canadian public discourse. Refuge, 25(1), 84-93. Retrieved August 11, 2012, from http://go.galegroup.com.ezproxy.lib.ryerson.ca/ps/infomark.do?action=interpret \&sPage $=84 \&$ source $=$ null\&prodId $=$ CPI\&userGroupName $=$ rpu_main\&searchTyp $\mathrm{e}=$ AdvancedSearchForm\&type $=$ DIourl\&queryId $=$ Locale $\% 28 \mathrm{en} \% 2 \mathrm{CUS} \% 2 \mathrm{C} \% 2$ 9\%3AFQE\%3D\%28sn\%2C9\%290229-5113\%3AAnd\%3AFQE\%3D\%28v

Becklumb, P. (2008, September 16). Canada's inland refugee protection system (BP185E). Parliament of Canada Website. Retrieved August 10, 2012, from http://www.parl.gc.ca/Content/LOP/researchpublications/bp185e.htm\#Background

Beiser, M., \& Feng, H. (2006). Gender differences in language acquisition and employment consequences among SEA refugees in Canada. Social Science and Medicine, 63(1). Retrieved February 21, 2012, from http://www.sciencedirect.com.ezproxy.lib.ryerson.ca/science/article/pii/S027795 $360500688 \mathrm{X}$

Bradimore, A., \& Bauder, H. (2011). Mystery ships and risky boat people: Tamil refugee migration in the newsprint media. Canadian Journal of Communication, 36, 367661.

Canadian Council for Refugees (2012, February 22). Bill C-31 - rolling back refugee 
protection: at what cost? Canadian Council for Refugees. Canadian Council for Refugees. Retrieved July 27, 2012, from http://ccrweb.ca/en/refugee-reform

Chimni, B. (2009). The birth of a discipline: from refugee to forced migration studies. Journal of Refugee Studies, 22(1), 11-29. Retrieved August 11, 2012, from http://jrs.oxfordjournals.org.ezproxy.lib.ryerson.ca/content/22/1/11

Citizenship and Immigration Canada (2011). Annual Report to Parliament on Immigration 2010. Ottawa: Citizenship and Immigration Canada.

Citizenship and Immigration Canada (2012, February 2). Backgrounder: summary of changes to Canada's refugee system in the Protecting Canada's Immigration System Act. Welcome Page. Retrieved July 20, 2012, from http://www.cic.gc.ca/english/department/media/backgrounders/2012/2012-0216f.asp

Citizenship and Immigration Canada (2012, June 29). The refugee system: humanitarian and compassionate review. Welcome Page. Retrieved August 11, 2012, from http://www.cic.gc.ca/english/refugees/inside/h-and-c.asp

Citizenship and Immigration Canada (2012, August 7). Designated countries of origin. Welcome Page. Retrieved July 21, 2012, from http://www.cic.gc.ca/english/refugees/reform-safe.asp

Citizenship and Immigration Canada (2012, August 17). The refugee system: resettlement from outside Canada. Welcome Page . Retrieved July 19, 2012, from http://www.cic.gc.ca/english/refugees/outside/index.asp

Citizenship and Immigration Canada (2012, August 17). What Canada is doing to help refugees. Welcome Page. Retrieved July 20, 2012, from http://www.cic.gc.ca/english/refugees/help.asp

Citizenship and Immigration Canada (2012). Document Checklist - Worker. (n.d.). Citizenship and Immigration Canada. Retrieved July 18, 2012, from http://www.cic.gc.ca/english/pdf/kits/forms/IMM5556E.PDF

Citizenship and Immigration Canada (2012). Preliminary tables: permanent and temporary residents, 2011. Welcome Page . Retrieved July 9, 2012, from http://www.cic.gc.ca/english/resources/statistics/facts2011-preliminary/01.asp

Citizenship and Immigration Canada (2012). Interim Federal Health Program: summary of benefits. Welcome Page. Retrieved July 10, 2012 from http://www.cic.gc.ca/english/refugees/outside/summary-IFHPp.asp

Cholewinski, R., \& Taran, P. (2010). Migration, governance and human rights: contemporary dilemmas in the era of globalization. Refugee Survey Quarterly, 28(4). Retrieved February 1, 2012, from http://journals1.scholarsportal.info.ezproxy.lib.ryerson.ca/details- 
sfx.xqy?uri=/10204067/v28i0004/1_mgahrcditeog.xml

Coates, T., \& Hayward, C. (2004). The costs of legal limbo for refugees in Canada: a preliminary study. Refuge, 22(2). Retrieved February 20, 2012, from http://pi.library.yorku.ca/ojs/index.php/refuge/article/view/21333

Cresswell, T., \& Merriman, P. (2011). Geographies of mobilities: practices, spaces, subjects.. Farnham: Ashgate Pub.

DeVoretz, D., Pivnenko, S., Beiser, M. (2004). The Economic Experiences of Refugees In Canada. Discussion Paper Series Institute for the Study of Labour. Retrieved February 20, 2012 from ftp://ftp.iza.org/pub/SSRN/pdf/dp1088.pdf

Dobson, S. (2004). Cultures of exile: an examination of the construction of 'refugeeness' in contemporary Norwegian society. New York City: Bern.

England, K. (1996). They think you're as stupid as your English is": constructing foreign domestic workers in Toronto. Environment and Planning, 29, 195-215. Retrieved August 10, 2012, from http://faculty.washington.edu/england/TheyThink.pdf

Fitzpatrick, M. (2012, June 29). Refugee health wrong priority for provinces, Kenney says. $C B C$ News. Retrieved from http://www.cbc.ca/news/politics/story/2012/06/29/pol-kenney-refugee-health.html

Gillis, A. \& MacLennan, M. (2010). Service learning with vulnerable populations: review of the literature. International Journal of Nursing 7:1. Retrieved April 5, 2012 from http://web.ebscohost.com.proxy1.library.mcgill.ca/ehost/pdfviewer/pdfviewer?sid $=37$ be6f64-a467-4b29-9337-e40c7211fc38\%40sessionmgr14\&vid=2\&hid=18).

Goldring, L. (2010). Temporary foreign worker programs as precarious status . Canadian Issues, 50-54. Retrieved August 11, 2012, from http://ezproxy.lib.ryerson.ca/login?url=http://search.proquest.com/docview/6107 80363 ?accountid=13631

Hadak, L., Holzinger, I., \& Zikic, J. (2010). Barriers and paths to success. Journal of Managerial Psychology, 25(2), 159-176. Retrieved August 9, 2012, from http://journals2.scholarsportal.info/detailssfx.xqy?uri=/02683946/v25i0002/159_bapts.xml

Hancock, A. (2004). The politics of disgust: the public identity of the welfare queen. New York: New York University Press.

Hopkins, P. (2007). Positionalities and Knowledge: Negotiating Ethics in Practice. ACME: An International E-Journal for Critical Geographies, 6 (3), 386-394. Retrieved April 12, 2012, from http://www.acme-journal.org/vol6/PEH.pdf

Hosada, M., \& Stone-Romero, E. (2010). The effects of foreign accents on employment- 
related decisions. Journal of Managerial Psychology, 25(2). Retrieved February 2, 2012, from

http://search.proquest.com.ezproxy.lib.ryerson.ca/docview/215870711

Instances of refugee claimants and migrants trying to enter Canada. (2010, August 13).

The Toronto Star. Retrieved July 23, 2012, from

http://www.thestar.com/news/canada/article/847888--instances-of-refugee-

claimants-and-migrants-trying-to-enter-canada

Itzigsohn, J., \& Giorguli-Saucedo, S. (2005). Incorporation, transnationalism, and gender: immigrant incorporation and transnational participation as gendered processes.

International Migration Review, 39(4). Retrieved July 23, 2012, from

http://search.proquest.com.ezproxy.lib.ryerson.ca/docview/215272706

Krahn, H., Derwing, T., Mulder, M., \& Wilkinson, L. (2000). Educated and underemployed: refugee integration into the Canadian labour market. Journal of International Migration and Integration, 1(1), 59-84.

Lacroix, M. (2004). Canadian Refugee Policy and the Social Construction of the Refugee Claimant Subjectivity: Understanding Refugeeness. Journal of Refugee Studies 17 (2). Retrieved February 19, 2012 from http://journals1.scholarsportal.info.ezproxy.lib.ryerson.ca/tmp/144387735858829 41146.pdf

Lenard, P., \& Straehle, C. (2010). Temporary labour migration: exploitation, tool of development, or both? Policy and Society, 29(4), 283-294. Retrieved August 11, 2012, from http://www.sciencedirect.com.ezproxy.lib.ryerson.ca/science/article/pii/S144940 $351000038 \mathrm{X}$

Létourneau, J. (2001). The question of identity: past findings and future outlook. Paper commissioned by the Canadian Heritage Multiculturalism Program. Retrieved August 5, 2012 from http://canada.metropolis.net/events/ethnocultural/publications/letourneau_e.pdf

Li, P. S. (2003). Destination Canada: immigration debates and issues. Don Mills, Ont.: Oxford University Press.

Malkki, L. (1995). Refugees and exile: from "refugee studies" to the national order of things. Annual Review of Anthropology, 24(1). Retrieved June 5, 2012, from http://www.jstor.org.ezproxy.lib.ryerson.ca/stable/10.2307/2155947?origin=api

Manjikian, L. (2010). Refugee inbetweeness: a proactive existence. Refuge, 27(1), 50-58. Retrieved August 16, 2012, from http://pi.library.yorku.ca/ojs/index.php/refuge/article/viewFile/34355/31262

Mann, A. (2009). Refugees who arrive by boat and Canada's commitment to the refugee convention: a discursive analysis. Refuge, 26(2). Retrieved July 20, 2012, from 
http://go.galegroup.com.ezproxy.lib.ryerson.ca/ps/retrieve.do?retrieveFormat=P DF_FROM_CALLISTO\&inPS=true\&prodId $=$ AONE\&userGroupName $=$ rpu_ma in\&workId=PI-0NDV-2009-FAL00-IDSI-189.JPG\%7CPI-0NDV-2009-FAL00IDSI-190.JPG\%7CPI-0NDV-2009-FAL00-IDSI-191.JPG\%7CPI-0ND

Marx, Karl. 2001 [1867]. Das Kapital: Kritik der politischen Ökonomie. Erstes Buch, der Produktionsproze des Kapitals, Karl Marx, Friedrich Engles: Werke, No. $23\left(20^{\text {th }}\right.$ edition) Berlin: Karl Dietz Verlag.

Mata, Fernando (1999) "The Non-Accreditation of Immigrant Professionals in Canada: Societal Dimensions of the Problem". Retrieved February 18, 2012 from http://canada.metropolis.net/research-policy/conversation/matapaper.html

Peck, J. (2001). Workfare states. New York: Guilford Press.

Piore, M. (1979). Birds of passage: migrant labour and industrial societies. Cambridge Cambridge University Press.

Pozniak, K. (2009). Talking the immigrant talk: immigration narratives and identity construction among colombian newcomers. Canadian Ethnic Studies, 41(1-2), 173-190. Retrieved August 10, 2012, from http://search.proquest.com.ezproxy.lib.ryerson.ca/docview/898610579/fulltextPD F? accountid $=13631$

Prefontaine, J.P. \& Benson, A. (1999). Barriers to Canadian Immigrants' Economic Integration: Government Response to Market Failure. Presentation given January 1999 in Vancouver, British Columbia at Third National Metropolis Conference. Retrieved Feburary 18, 2012 from www.rim.metropolis.net/Virtual\%20 Library/1998/NC/Benson.pdf

Reitz, J. (2001). Immigrant success in the knowledge economy: institutional change and the immigrant experience in Canada, 1970â€" 1995. Journal of Social Issues, 57(3), 579-613. Retrieved August 10, 2012, from http://journals2.scholarsportal.info.ezproxy.lib.ryerson.ca/detailssfx.xqy?uri=/00224537/v57i0003/579_isitketieic1.xml

Reitz, J. (2005). Tapping immigrants' skills: new directions for Canadian immigration policy in the knowledge economy. Law and Business Review of the Americas, 11. Retrieved February 1, 2012, from http://search.proquest.com.ezproxy.lib.ryerson.ca/docview/194668903

Sawyer, C., \& Turpin, P. (2005). Neither here nor there: temporary admission to the UK. International Journal of Refugee Law, 17(4), 688-728.

Strauss, A. L. (1987). Qualitative analysis for social scientists. Cambridgeshire: Cabridge University Press.

Teelucksingh, C., \& Galabuzi, G. (2005). Working Precariously: the Impact of Race and 
Immigrant Status on Employment Opportunities in Canada. In T. Gupta (Ed.), Race and Racialization (pp.202 - 209). Toronto, Ontario: Canadian Scholars' Press Inc.

Tories' sweeping immigration reforms target influx of claims from Roma gypsies (2012, February 16). The National Post. Retrieved July 2, 2012, from http://news.nationalpost.com/2012/02/16/conservatives-to-announce-furtherbarriers-to-deter-bogus-refugee-claimants-report/

Welfare tab to grow for Tamil refugees (2010, August 18). Toronto Sun. Retrieved July 3, 2012, from http://www.torontosun.com/news/torontoandgta/2010/08/18/15067496.html

Wesley, J. (2011). Observing the Political World: Quantitative and Qualitative Approaches . In Archer \& Berdahl (Eds.), Explorations: Conducting Empirical Research in Canadian Political Science (pp. 123 - 144; 350 - 359). Don Mills, Ontario: Oxford University Press.

Work Permits and SIN (n.d.). FCJ Refugee Centre. Retrieved February 1, 2012, from http://www.fcjrefugeecentre.org/?p=610

Zucchino, D. (1997). Myth of the welfare queen: a Pulitzer prize-winning journalist's portrait of women on the line. New York: Scribner. 